\title{
Developing Long-Term Business Performance through Supplier Network and Company Capability
}

\author{
Lena Ellitan, Robertus Sigit H. L \\ Lecturer, Widya Mandala Catholic University Surabaya, Indonesia
}

\begin{abstract}
This study is an exploratory study on small companies to investigate and explain how SMEs in Surabaya build supplier networks and enhance dynamic capabilities. This study is important due to not many studies explaining how the strength of supplier's network strategy, the synergy of collaboration, and dynamic capabilities are able to explain the variations of performance through the role of strategies development. Based on 41 respondents from SMEs in Surabaya that participated in this study, there are several findings that need to be highlighted include: business development can be done by improving and evaluating suppliers' networks; collaboration with entry networks is very important in the development of SMEs; business development strategies planned and carried out by SMEs since business development must prioritize the role of partnerships and synergies between SMEs and suppliers; cooperative strategy with suppliers accelerates the innovation process undertaken by SMEs that lead to the acceleration of business development; SMEs need to collaborate with other companies to absorb new knowledge to increase their resources competence.
\end{abstract}

KEY WORDS: supplier network strategy, dynamic capability, business performance

\section{INTRODUCTION}

Harland and Knight (2000) suggest the importance supply networks role for companies to play more active and optimal role in managing and operating supplier networks which include product design, production, suppliers, marketing and distribution, which are then coordinated and adapted to environmental and market conditions. In its development, the concept of supplier strategy entered a new phase in the development of corporate strategy known as supply network management which focuses on solving business process problems that are important for customers (retail). The goal is to be flexible, quickly supply defect-free products in the chain, and get rid of all unnecessary costs and time lags (Chandra \& Kumar, 2000).

Academics and researchers recognize the importance of collaboration between companies as a corporate asset strategy. Marketers must focus on continuously maintaining the relationship between their customers and suppliers. The research also measures how an organization enters the market through partner collaboration and develops an understanding of factors influences, developing and managing partner relations strategies within the scope of supply network management. Consistent with this, other studies also prove the importance of inter-company cooperation in the description of company's or supplier's strategy (Johnson, 1999).

Research conducted by Ferdinand (2004) suggests that integrated distribution systems can cause companies to have more controlled sales and marketing management processes and which in turn improve marketing performance. However, the research has not yet explained how the mechanism can produce more controlled management process, therefore this research is conducted to explain what kind of mechanism will result in integrated sales and marketing management processes. Some evidence suggests that the influence of long-term relationships provides optimal marketing performance, both for suppliers and retailers (Johnson, 1999). Likewise with the direction of future research on research conducted by Campbell (1998) began with the limitations of the study, where companies continued to find ways to increase their effectiveness and improve their baseline. One updated topic area is Supply Network 
Strategy. Research conducted by Peng (2016) on supplier chain management capabilities and information technology capabilities on company performance shows significant results regarding the influence of supplier chain management capabilities on company performance.

The phenomenon shows that the main weaknesses of SMEs inherent in conducting capability evaluation is the absence of qualified economic knowledge from top management, as well as excessive orientation towards technical problem solving without business problems consideration such as management and market strategies. Formal planning or market-oriented results or cost control are only done uncertainly. In addition, the instrument of decision making is usually only carried out by a small number of individuals and is developed more intuitively than in a theoretical way (Terziovski, 2007).

There are not many empirical studies that show how the strength of supplier network strategy, synergy of cooperation, dynamic capability mightexplained the variation of performance through the role of business development strategy.It drives the research and become novelty of the research. Therefore, exploration was carried out on small companies related to how to build a supplier network and increase dynamic capabilities in SMEs in Surabaya especially before developing an empirical study. Based on the description in the background of the study, the main problems to be explored in this study include: 1) how do SMEs build supplier network strategies? 2) What is the importance of business development supplier network strategy? 3) How do SMEs build synergies between SMEs in business development? 4) What is the SME strategy in building company capability? 5) What is the role of company capabilities in business development? 6) How can network strategy, cooperation, capability improve business strategies.

\section{Theoretical Review}

\section{Supplier Network Strategy}

Optimization and integration of supplier networks has become the focus and objective of most companies around the world. The concept of supplier network strategy is a new scheme of supply chain strategies that emerge and develop broadly or globally. Supply network strategy is a new concept of management and philosophy of supply chain management that was born as a solution for decision makers to face the increasingly complex problems. In the operating line and firmly rooted in the supplier performance company, the existence of supply network strategy focuses on developing supplier performance through a supply network. Harland and Knight (2000) define the role of supply network for company as a media where companies will be able to play a more active and optimal role in managing and operating supplier networks which include product design, production, supplier, marketing and distribution, then all these elements are coordinated and adapted to environmental and market conditions.

\section{Strength of Cooperation Relations}

Cooperation is a relationship between two or more entities (people or organizations) to achieve one or more common goals. In the sociological context Lings (2000) explains that humans are social beings who need other individuals. Humans are members of other groups: groups, associations and institutions. So the nature of cooperation is natural, it is human need as social being, where no one can avoid "needing another party." Hage (1994) defines that collaboration between organizations includes efforts that are simple relationships, such as: exchange of information, to complex relationships such as producing shared products. These efforts include very broad activities, and form a series of inter-partner activity units. Axelrod (2000) divides the pattern of collaboration between organizations into three categories, namely: collaboration between similar companies (horizontal cooperation), complementary cooperation, or multibusiness cooperation (among stakeholders, both similar, substitution and complementary businesses (for example: financial institutions/ financing parties. This inter-business collaboration for companies can be done in the form of sharing: strategic resources, risks, knowledge, technology, market information, market control, and can even be used as collaborations to block newcomers or block imitations (Barney 1991). This can be achieved because business people in networking will have strong competitive positional advantages when the partnership is successful.

\section{Company Capability}

Capability enables companies to create and exploit external opportunities and develop excellence that is resilient when used with insight and agility (Hitt et al., 2001). Capability is identical to the ability, expertise and knowledge of organization members, capability enable of providing strategic, creative and science and 
technology-based solutions for the company. Hayes et al., (1996) consistently emphasize that strategic capability plays an important role for companies to survive in competition; therefore it must be developed continuously. The resources owned by the company are combined, the results become a number of capabilities, which are the expertise found in individual member of the company (Hunger \&Wheelen, 2003). Capability is important when it is uniquely combined to create core competencies that have strategic value and can generate competitive advantage.

The results of the study show that the dynamic capabilities of an organization are the relationships between ranged factors that are complex. This is in line with the concept of Teece et. al. (1997) that the process of developing organization dynamic capabilities must go through a series of processes with three main roles, namely: (1) rules regarding coordination / integration (static concepts), (2) learning (dynamic concepts), (3) configuration (transformational concept). The existence of these three principles is likely to be the factors influence dynamic capabilities with the complex relationship patterns. Organizational learning is a process to get this dynamic capability.

\section{Business Performance}

There are several criteria in assessing company's performance presented in various literature. These criteria include financial and non-financial performance. Different criteria in measuring the company's performance actually depend on the performance measurement itself. These differences will affect the behavior of business entities, and by themselves also affect the performance and benchmarks used (Hadjimonalis, 2000). Miles et. al., 2000 suggested that subjective measurements of performance were chosen rather than objective measurements. Previous research indicates that subjective performance can be consistent with objective measurements and enhance the research reliability and validity (Ciptono, 2006).

Business performance can be understood as medium to measure the results that have been achieved by company for a certain period of time. From business performance assessment, it will be known whether the company's improvement efforts have positive impact or not. Various companies have different ways of measuring their business performance. However, measurement of this performance can basically be classified into two main parts, namely financial and marketing performance measurement (Ferdinand, 2000b).

\section{Research methods}

The exploratory approach used in this study is mainly related to the development of supplier networks, synergies between organizations in supply chain and organizational capabilities. Data collected through interviews with companyleaders that are willing to participate in the research using a semi-structured questionnaire. Samples were obtained from manufacturing company directories published by the Indonesian Central Statistics Agency 2017. The researcher will also collect information from secondary data and will cross check the information provided by company leaders to the relevant functional or division fields. More or less interviews were conducted for 2.5 hours (flexible in accordance with conditions in the field). This interview focus on issues related to research objectives. This research is expected to involve at least 25-30 SMEs representing all business categories or business fields. Qualitative data analysis used in this study due to the empirical data obtained is qualitative in the form of tangible assemblages of words and not a series of numbers that cannot be arranged in categories / classification structures (Sugiyono, 2013).

\section{Data analysis}

\section{Characteristics of Respondents}

Based on the age characteristics, the youngest respondent was 29 years old and the oldest was 55 years. The average age of respondents who participated in this study was 39 years with a standard deviation of 7.5 years. By sex, of the total 41 respondents who participated in this study, 26 respondents were male and 15 were female. Based on education level, the majority of respondents have undergraduate education with a percentage of $43.9 \%$ followed by diploma levels with a percentage of 26 , $83 \%$ (11 respondents), post-graduate with a percentage of $21.95 \%$ ( 9 respondents), and a small percentage have high school education level of 7 , $32 \%$ (3 respondents).

\section{Some Aspects Assessed}

Some aspects assessed in this study include aspects of supplier network strategy, synergy aspects of collaboration, aspects of dynamic capability, aspects of business development strategies, and aspects of 
business performance. These four aspects will be discussed in detail in the next section.

Supplier Network Strategy: The supplier network strategy aspect includes supplier trust, supplier communication, and supplier environmental dynamics.

\section{A. Supplier Trust}

Table 1 summarizes respondents' assessments of the three aspects of supplier trust include quality maintenance, overseeing the quality of delivery services according to the type of order, overseeing the quality of delivery services according to the number of orders. The average value of 2.77 in this study means that overall respondents who participated in this study have moderate tendency in terms of supplier trust.

\begin{tabular}{|c|c|c|c|}
\hline No & Supplier Trust & Mean & $\begin{array}{c}\text { Std. } \\
\text { Deviasi }\end{array}$ \\
\hline 1 & Quality maintenance & 2.87 & 1.127 \\
\hline 2 & Quality of delivery service & 2.91 & 1.118 \\
\hline 3 & $\begin{array}{l}\text { Control on quality of } \\
\text { delivery service }\end{array}$ & 2.83 & 1.201 \\
\hline & Supplier Trust & 2.77 & 1.149 \\
\hline
\end{tabular}

\section{B. Supplier communication}

Supplier communication in this study consists of two aspects include: the company is able to foster good communication with suppliers and companies communicate to solve every problem and integration of sales. Table 2 presents the informant's assessment of the supplier's aspects of full communication. The average value is 3.045 and the standard deviation is 1.133 which means that overall the respondents are participating in this study.

\section{TABLE2. SUPPLIER COMMUNICATION}

\begin{tabular}{|c|l|c|c|}
\hline No & Supplier Communication & Mean & $\begin{array}{c}\text { Std. } \\
\text { Deviasi }\end{array}$ \\
\hline 1 & $\begin{array}{l}\text { Company is able to foster } \\
\text { good communication with } \\
\text { suppliers }\end{array}$ & 2.95 & 1.119 \\
\hline 2 & $\begin{array}{l}\text { Companies to communicate } \\
\text { to solve every problem and } \\
\text { integration of sales. }\end{array}$ & 3.14 & 1.147 \\
\hline \multicolumn{2}{|l|}{ Supplier Communication } & 3.045 & 1.133 \\
\hline
\end{tabular}

\section{Environmental Dynamics of Suppliers}

The dynamics of the supplier environment in this study consisted of two aspects which included the company responding to the strategies applied by competitors and the company responded to the increasing types of substitution products. Respondent's assessment on supplier's environmental dynamics aspects is presented in Table 3. The average value is 2.96 and the standard deviation is 1.093 meaning that overall the respondent responds likely to agree to the statements of the supplier's environmental dynamics indicators.

\section{TABLE3. ENVIRONMENTAL DYNAMICS OF SUPPLIERS}

\begin{tabular}{|c|c|c|c|}
\hline No & $\begin{array}{l}\text { Environmental Dynamics } \\
\text { of Suppliers }\end{array}$ & Mean & $\begin{array}{l}\text { Std. } \\
\text { Deviasi }\end{array}$ \\
\hline 1 & $\begin{array}{l}\text { Company responding to the } \\
\text { strategies applied by } \\
\text { competitors }\end{array}$ & 2.93 & 1.087 \\
\hline 2 & $\begin{array}{l}\text { Company responded to the } \\
\text { increasing types of } \\
\text { substitution products }\end{array}$ & 2.99 & 1.098 \\
\hline & $\begin{array}{l}\text { Environmental Dynamics of } \\
\text { Suppliers }\end{array}$ & 2.96 & 1.093 \\
\hline
\end{tabular}

\section{Supplier Network Strategy}

The indicators of supplier network strategy consist of supplier trust, supplier communication and supplier environmental dynamics. Table 4 provides complete overview of respondents' assessments on supplier network strategy indicators. The average value of the respondent's answer to the supplier network strategy is 2.93 and the standard deviation of 1.125 means that overall the respondent responds likely to agree to the statements of the supplier network strategy indicators which consist of statements related to supplier trust, supplier communication, and supplier environmental dynamics.

\section{TABLE 4. SUPPLIER NETWORK STRATEGY}

\begin{tabular}{|c|l|c|c|}
\hline No & \multicolumn{1}{|c|}{$\begin{array}{c}\text { Supplier Network } \\
\text { Strategy }\end{array}$} & Mean & $\begin{array}{c}\text { Std. } \\
\text { Deviasi }\end{array}$ \\
\hline 1 & Supplier Trust & 2.77 & 1.149 \\
\hline 2 & Supplier Communication & 3.05 & 1.133 \\
\hline 3 & $\begin{array}{l}\text { Supplier Environmental } \\
\text { Dynamics }\end{array}$ & 2.96 & 1.093 \\
\hline & $\begin{array}{l}\text { Supplier Network } \\
\text { Strategy }\end{array}$ & 2.93 & 1.125 \\
\hline
\end{tabular}




\section{Cooperation Synergy}

The synergy of collaboration has important aspects, namely market access, cost savings, access to information and sensitivity. Table 5. provides a complete overview of respondents' assessments on indicators of synergy in collaboration both related to market access, cost savings, access to information, and sensitivity. The average value of respondents' answers to statements related to collaboration synergy is 3.14 and a standard deviation of 1.094 means that overall the respondent tend to agree with the statements of the synergistic indicators of cooperation.

TABLE5. COOPERATION SYNERGY

\begin{tabular}{|c|c|c|c|}
\hline No & Cooperation Synergy & Mean & $\begin{array}{c}\text { Std. } \\
\text { Deviasi }\end{array}$ \\
\hline 1 & Market Access & 3.11 & 1.093 \\
\hline 2 & Cost Savings & 3.01 & 1.071 \\
\hline 3 & Access to Information & 3.29 & 1.109 \\
\hline 4 & Sensitivity. & 3.16 & 1.102 \\
\hline \multicolumn{2}{|c|}{ Cooperation Synergy } & 3.14 & 1.094 \\
\hline
\end{tabular}

\section{Dynamic capability}

Dynamic capability has two indicators consist of exploitation capabilities and development capabilities. The completed respondent's assessment dynamic capability aspects is presented in Table 6 . The average value of the respondent's answers related to statements of 3.10 and standard deviation 1.125 means that overall the respondents tends to agree on the existence of dynamic capabilities.

TABLE6. DYNAMIC CAPABILITY

\begin{tabular}{|c|c|c|c|}
\hline No & Dynamic Capability & Mean & $\begin{array}{c}\text { Std. } \\
\text { Deviasi }\end{array}$ \\
\hline 1 & Exploitation Capabilities & 3.15 & 1.119 \\
\hline 2 & Development Capabilities & 3.05 & 1.131 \\
\hline \multicolumn{2}{|c|}{ Dynamic Capability } & 3.10 & 1.125 \\
\hline
\end{tabular}

\section{Business Development Strategy}

Business development strategy has four indicators consists of market penetration, market expansion, product development, and product differentiation. Respondent's assessment on the indicators of business development strategy is presented in Table 7. The average value of respondents' answers to the statements related to business development strategies is 3.41 and the standard deviation of 0.940 means that as respondents tend to agree with the statements related to business development strategies indicators.
TABLE7. BUSINESS DEVELOPMENT STRATEGY

\begin{tabular}{|c|l|c|c|}
\hline No & \multicolumn{1}{|c|}{$\begin{array}{c}\text { Business Development } \\
\text { Strategy }\end{array}$} & Mean & $\begin{array}{c}\text { Std. } \\
\text { Deviasi }\end{array}$ \\
\hline 1 & Market Penetration & 3.47 & .943 \\
\hline 2 & Market Expansion & 3.39 & .937 \\
\hline 3 & Product Development & 3.49 & .949 \\
\hline 4 & Product Differentiation & 3.29 & .931 \\
\hline \multicolumn{2}{|l|}{ Business Development Strategy } & 3.41 & 0.940 \\
\hline
\end{tabular}

\section{Business Performance}

The measurement aspect of business performance consists of sales turnover, market share, profitability, popularity and number of customers. Respondent's assessment of the indicators of complete business performance is presented in Table 8 . The average value is 3.91 and the standard deviation is 1.115 meaning that overall the respondent responds tend to agree to the statements of business performance indicators which include sales turnover, share market, profitability, popularity and number of customers.

TABLE8. BUSINESS PERFORMANCE

\begin{tabular}{|c|c|c|c|}
\hline No & Business Performance & Mean & $\begin{array}{c}\text { Std. } \\
\text { Deviasi }\end{array}$ \\
\hline 1 & Sales Turnover & 3.87 & 1.113 \\
\hline 2 & Market Share & 4.13 & 1.121 \\
\hline 3 & Profitability & 3.77 & 1.109 \\
\hline 4 & Number of Customers & 3.95 & 1.119 \\
\hline \multicolumn{2}{|c|}{ Business Performance } & 3.91 & 1.115 \\
\hline
\end{tabular}

\section{Discussion}

SMEs are currently trying to continuously develop their resources and capabilities to improve competitive advantage. In addition, SMEs also strive to build partnerships and synergic cooperation with supplier network to expandtheir market share and manage capabilities to be more dynamic, improve organizational members skills, expertise and knowledge (both management and employees) that have not been optimally managed.

\section{The Urgency of Supplier Network Partnership}

The efforts to improve supplier network are important for company to strengthen the relationship between suppliers and SMEs (Kurniawan, et al., 2018). The strategy of good supplier network development can be done through building trust, active communication with suppliers, and good understanding of what is happening in the business environment (Lee et al., 2008; Muljani, 2017). This can be the source of increasing SMEs competitiveness. Through careful 
planning and coordination in the network, SMEs are better able to align the framework of supplier network and are able to create structures that are in line with the company's objectives to provide maximum service to its customers (Ellitan, 2017a). This study also supports research conducted by Wheelen, Hunger and Hoffman (2016) which examines the relationship between company's business strategy and supplier network management. Wheelen, et al. (2016) found the phenomenon that supplier network strategies have an important role in running business strategies conducted by SMEs.

The ability of SMEs to manage supplier networks will create alignment between SMEs goals and strategies with suppliers so that they can drive the SME operating process (Anatan\&Ellitan, 2009). The lack of capacity of SMEs in building a good supplier network reduces production optimization (McAfee et al., 2002). The inability to handle the supply chain, especially building cooperation with existing suppliers will lead to the decrease in SMEs operational effectiveness, so that the implementation of business development and strategies are not able to achieve the targets they have set.

Developing supplier network is very important in dealing with business competition as strategy in developing SMEs competitive advantage. Supplier partnership strategies have important role in the management innovation process. Therefore, the partnerships built with suppliers and the innovation process are aligned and plays important role in dealing with SME business competition.

\section{Collaboration with Suppliers and SME Business Development}

Collaboration in the supply chain between SMEs and suppliers will increase effectiveness and productivity (Ellitan\&Anatan, 2007). It is very important to create service excellence in a service-driven economy (Ellitan\&Anatan, 2007). Through this strategy SMEs can improve their ability to develop the business that will be carried out. The results of this study are in line with Martin's (2016) study which found that the dynamic environmental conditions effects the dynamics of the SME business environment. This dynamic should accelerate the efforts of SMEs to accommodate changes. This creates a tighter competition potential and development in product technology and process technology (Ellitan\&Anatan, 2009). Collaboration established by SMEs is expected to create relationships to build and enhance the dynamic capabilities of SMEs facing the turmoil of changes in the business environment (Permana, et al., 2017).

Collaboration with the supplier network will create synergy to make it easier to achieve common goals. Synergies with suppliers lead to the growing opportunities for SMEs in accordance with customer demands and competition. Zhou and Zhang (2011) suggested that the development strategy of companies in similar industries or related industries would have many effects on many aspects such as economies of scale, structural integration of industrial chains, strong alliances and complementary benefits, so that they could affect the company survival. This will facilitate SMEs to prioritize cooperation with suppliers and networks in the supply chain

Failure to create synergies in the supply chain is very likely to create problems in joint decision making that are important for SMEs and suppliers. The collaboration between SMEs and suppliers influences the SMEs business development process. This collaboration will provide SMEs ability to analyze various strategic decisions, competitive environment, and plan action mechanisms that important in winning SMEs competition. Paulraj, Chen and Lado (2012) suggested that collaboration with suppliers would improve product and process innovation acceleration.

\section{The Importance of Dynamic Capability in Partnerships with Suppliers}

Companies that are able to extract resource capabilities now become the next superior resource capability through the development of new competencies so that company tends to have qualified resources that will be able to support the strategy in business development to be carried out (Kurniawan, et al., 2018). SMEs cannot only rely on the resources they have in carrying out business development strategies, but also required to be able to do business partnerships with various parties, both with suppliers, distributors and even consumers. Through partnership strategy, SMEs are better able to absorb variety of new knowledge and skills that can be used to develop competencies from existing resources. Tairas et al (2016) found that dynamic capability is important for the success of a company's business strategy. This capability is an integration of various organizational resources that develop through a complex interaction process between tangible and intangible assets owned 
by the organization. With the capabilities possessed by SMEs, they will be able to exploit external opportunities and develop long-term competitive advantages. Dynamic SME capabilities will also greatly support the success of entrepreneurship strategies. However, this requires an innovative pumping role (Ellitan, Muljani, \&Koesworo, 2018).

Capability in managing alliance resources plays a role in increasing innovation and in turn will improve company performance. This is as stated by Ellitan and Anatan (2009) in their book entitled Innovation Management. Capability is built through organizational learning that enhances the ability of SMEs to utilize the resources they have or collaborate with other companies including suppliers. The capability of companies to build partnerships and synergies to improve skills and knowledge is the most appropriate predictor in improving innovation and performance.

\section{Partnership Strategy with Suppliers in Improving SME Performance}

SMEs that play more active role and optimally manage and operate the supply network will tend to be more easily in their operational process (Kurniawan et al 2018). The study findings support research conducted by Ellitan and Muljani (2017) which shows that environmental analysis direct management in analyzing factors that are a threat to SMEs. The results of this analysis direct SMEs in developing various ways and approaches to rearrange priorities. For example, the good distribution planning will provide higher business performance. By choosing the right supplier and synergizing it will get better results.

Supplier network strategy is one component of supply chain management that must be carried out to guide SMEs in determining the accuracy of strategies choice and operational capabilities of supplier companies in supporting SME performance. The ultimate goal to be achieved with SCM strategy is that SMEs focus more on mutual planning between SMEs and suppliers, able to do joint problem solving between companies and suppliers (Anatan\&Ellitan, 2009). Cooperation between SMEs also applies in the perspective of network marketing relations.

\section{Conclusion and Implication}

This study indicates that the supplier network strategy has important meaning in the SME business development strategy. In this case SMEs need to be supported by dynamic capabilities. The synergy created by cooperation with suppliers strongly supports the achievement of common goals and strengthens the competitiveness of SMEs. Collaboration with suppliers will also accelerate the development of SME's dynamic capabilities. Collaboration in the supply chain network, companies can add insight and knowledge about production and marketing strategies to smooth and improve overall business performance. Practically this research shows the importance of fostering good relationships with company suppliers, so that it will also make SMEs the top priority of suppliers to realize common goals.

Based on the results of this study, there are many suggestions that can be raised include: First, SMEs must prioritize partnerships and synergies in collaboration with suppliers to expand their market share. It should be done to increase competitiveness at national and global levels. Second, SMEs should make efforts to improve the quality of communication with suppliers and distributors so that the internal business environment can be better organized first by thereby strengthening the supply chain competitiveness. Thus SMEs will be stronger in fostering cooperative relationships with old suppliers or new suppliers, which accelerates the improvement of its performance.

Third, SMEs should continue to improve the workers skills and knowledge. Management must be able to compete in a dynamic business environment. This effort must be proceded by a comprehensive change of resources, especially human resources. Efforts to improve human resource competence are the first steps to face business competition. The competence of human resources is the main capital of SMEs to increase competitiveness.

\section{REFERENCES}

1. Anatan, L. \& Ellitan, L. 2009. Supply Chain Management: Teori dan Aplikasi, Alfabeta Bandung (ISBN:978-979-8433-99-3).

2. Axelrod, 2000, On six expand in Cooperation Theory. Prepared for a Special Issue.

3. Barney, J., 1991, Firm resources and sustained competitive advantage, Journal of Management, Vol, 17(1): pp.99-12.

4. Campbell, J. A., 1998, Cooperation in international value chains: comparing an 
exporter's supplier versus customer relationship, Journal of Business \& Industrial Marketing, Vol. 13 , No. 1, pp. 22-39.

5. Ciptono. W. S, 2006, A Sequential Model Of Innovation Strategy-Company Non- Financial Performance Links, Gajah Mada International journal ofBussiness, 8, 2, pp. 137-178.

6. Chandra, and, Sameer K., 2000, Supply chain magement in theory and practice: a passing fad or a fundamental change, Industrial Managemnet \& Data Systems, Vol. 100/3.

7. Ellitan, L. \& Anatan, L. 2007. Strategi Bersaing dalam Service Driven Economy, Andi Offset, Yogyakarta (ISBN: 978-979-29-0006-4).

8. Ellitan, L. \&Muljani, N. 2017. The Effect Of Information Sharing and Quality of Information on the Performance Of Supply Chain: The Case of East Java Manunufacturing SMEs, International Journal of Advanced Research, 5(7), 593-599.

9. Ferdinand, A., 2000a, Manajemen Pemasaran: Sebuah Pendekatan Stratejik, Research Paper Series, Magister Manage men Undip.

10. Ferdinand, A., 2004, Strategic Selling in Management, Research Paper Series Seri Penelitian Manajemen No. 03/Mark/2004.

11. Hadjimonalis, A., Keith D., 2000, Innovation Strategies of SMEs in Cyprus, A Small Developing Country, International Small BusinessJournal . 18,4, pp. 62-79.

12. Hage, Jerald, 1994, Organizational theory and the concept of productivity, In Productivity research in the behavioral and social sciences, ed, AP, Brief,

13. Harland, Christine, Louise Knight, Richard Lamming, and Helen Walker, 2005, Outsourcing: assessing the risks and benefits for organizations, sector and nations, International Journal of Operation \& Production Management, Vol, 25 (9): pp. 831-850.

14. Hayes, R. H. and Pisano, G. P, 1996, Manufacturing Strategy: At the Intersection of Two Paradigm Shifts. Production and Operations Management, 5 (1), pp. 25- 41.

15. Hitt, M. A., et al, 2005, Strategic Management: Competitiveness and Globalization. Sixth Edition. South-Western, USA.
16. Hunger. D. J, Wheelen. L. T, 1996, Strategic Management, Wesly Publishing company.inc, Agung. J (penerjemah). 2003, Penerbit Andi Jogyakarta.

17. Johnson, Jeans L. , 1999, Strategic Integration in Industrial Distribution supply network $\mathrm{s}$ : managing the Interfirm Relationship as a Strategic Asset, Journal of The academy of marketing science, vol.27, No. 1, pp.4-18.

18. Kurniawan R., B., Ellitan, L. 2018. Evaluation of Corporate Strategy and Dynamic Capability to Business Performance, International Journal of Scientific Research and Management (IJSRM), Volume 06, Issue 03, pp199-20.

19. Lee, C.W., Kwon, I.W.G. and Joo, S (2008). Severance, "Supply Chain Integration and Its Impact on Performance: A Structural Equation Model Approach North America Research/Teaching Symposium. 2008

20. Lings, N. Ian, 2000, Internal marketing and supply chain management, Journal of Services Marketing, Vol. 14, No. 1.Pp. 27-43

21. Miles, P Morgan., Covin G jefferey., Heeley b Michael, 2000, The Relationship Between Environmental Dynamism and Small Firm structure, strategy, and Performance. Journal of Marketing theory and Practice. pp. 63-74.

22. Permana, A., Laksmana, A., Ellitan, L. 2017. The Effect of Environmental Dynamism, Dynamic Managerial Capabilities, and Deliberate Organizational Learning on the SMEs Performance with Dynamic Capabilities ad Moderator Variable: A Case Study on Small SMEs in Surabaya, International Journal of Advances. Research, 5(7), 540-551.

23. Paulrak, A., Chen, I. J., \& Lado, A. A. (2012). An empirical taxonomy of supply chain management practices. Journal of Business Logistics, 33(3), 227-244. doi:10.1111/j.0000- 0000.2012.01046.x

24. Peng, Jianping, Quan Jing, 2016, Mediation effect of business process and supply chain managementcapabilities on the impact of IT on firm performance: Evidence from Chinese firms, International Journal of Information Management, 36, pp. 89-96.

25. Tairas, D.R., Kadir, A.R., Muis, M., \&Mardiana, R. 2016, The Influence of Strategic Leadership and Dynamic Capabilities through 
International Journal of Trend in Scientific Research and Development (IJTSRD) ISSN: 2456-6470

Entrepreneurship Strategy and Operational Strategy in Improving the Competitive Advantage of Private Universities in Jakarta, Indonesia, Scientific Research Journal (SCIRJ), Volume IV, Issue II, February 2016, pp. 8-18

26. Teece, David, 1997, Dinamic Capabilities and Strategic Managenment, Strategic Management Journal, Vol. 18: 7, pp. 509-533.
27. Terziovski, 2007, Building Innovation Capability in Organizations: An International Cross-case Perspective, Imperial College Press.

28. Wheelen, T. L., Hunger, J. D., Hoffman. L, 2016. Strategic Management and Business Policy: Globalization, Innovation and Sustainability, Pearson (14th Edition) 14th Edition

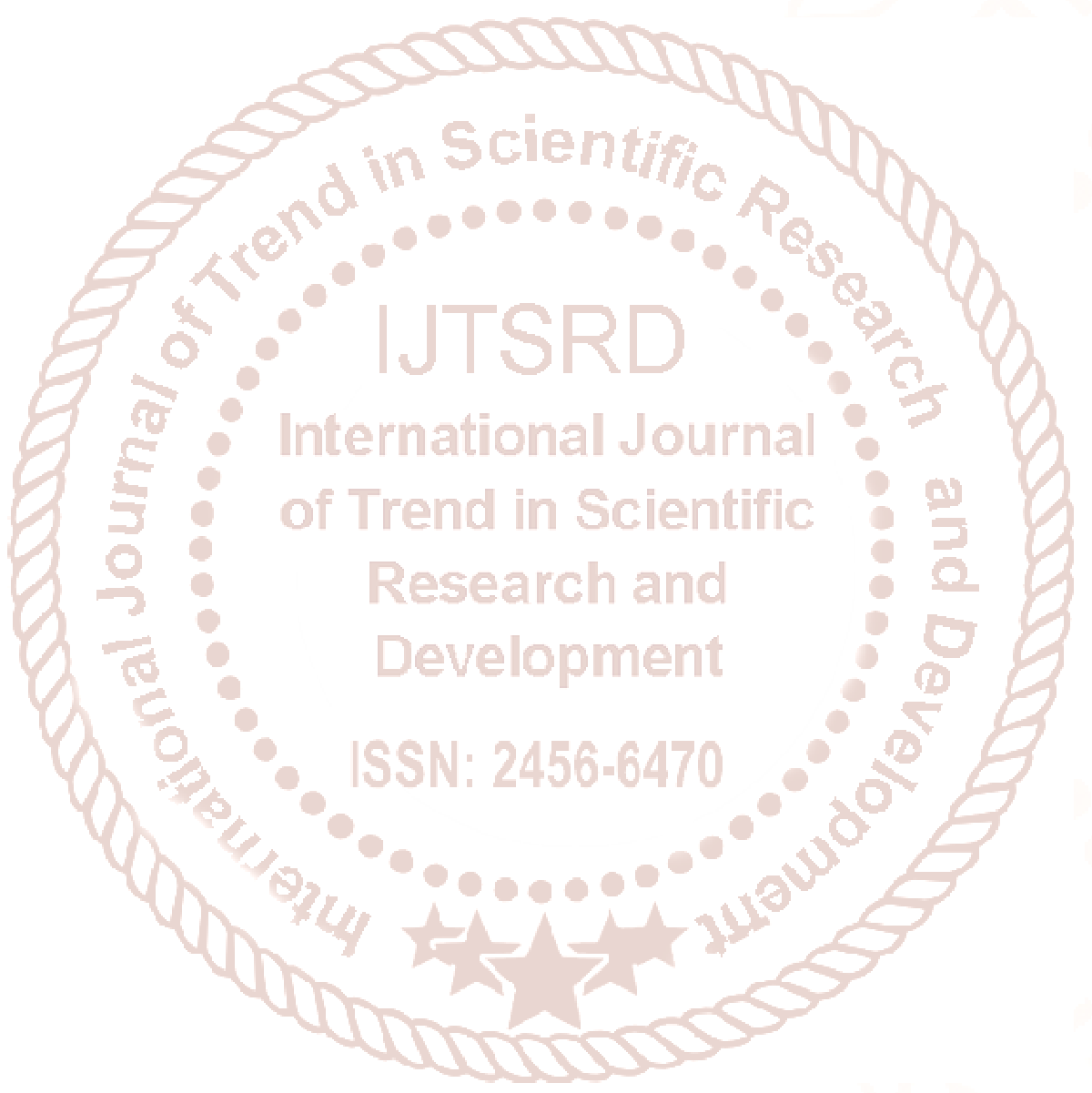

